\title{
The Aurunci and Sidicini
}

\section{Geography}

The Aurunci/Ausones and the Sidicini occupied the area between the Garigliano and the Volturno rivers (for a map of the region, see Map 2, p. 7; also see Fig. 2, p. 388). The area is formed of plains interrupted by two mountain ranges, the Monti Aurunci and the Monti Ausones (the latter dominated by the extinct but once powerful volcano Mt. Roccamonfina), and the Massico range which runs down to the coast. They are all part of the Anti-Apennines, which were formed between seven and five million years ago as a result of the African tectonic plate being carried under the European plate. Predominantly friable limestone, they represent a boundary between Latium Adjectum and the fertile Ager Stellas and the Campanian plain. Post-volcanic activity is demonstrated by thermal springs at Suoi Terme (Aquae Vescinae) and Bagni Sulfurei (Thermae Sinuessanae), and earthquake activity is well-attested archaeologically.

The upland parts of the area were probably heavily forested in prehistory, but partially deforested in classical times. The lower ground was well-watered and had considerable agricultural potential, becoming in classical times famous for viticulture. The close juxtaposition of hill and plain may have permitted local movement of flocks without the need for long distance transhumance, as could be observed until quite recently. The coastline was further inland than today, and there were a series of lagoons and grottoes, which encouraged fishing, but also harboured malaria, at least in Late Antiquity. The combination of this potential, and the high strategic significance of the area, especially once communications between Etruria, Latium and Campania began to increase, is the background to the complex history of this area (see Frederiksen 1984, 1-53; Arthur 1991; Zannini 2012).

\section{Sources}

What is so fascinating about this area between the Apennines and the Tuscanian Sea, is the number of ethnic groups, many quite fleeting. The Aequians, Hernicans

\footnotetext{
I am extremely grateful to Maria Cristina Biella, Massimiliano di Fazio, Francesco Maria Ciffarelli, Alessandra Pagliara and the editors for helpful advice and gentle corrections; all remaining errors are my own.
}

Christopher J. Smith: British School at Rome and School of Classics, University of St Andrews, Fife, Scotland KY16 9A); Email: cjs6@st-and.ac.uk 
and Volscians just to the north are treated elsewhere in this volume. The Ausones/ Aurunci and the Sidicini have a significant role in Livy's account of the fourth century BC, and played a role in the Hannibalic Wars, but are then largely the subject of learned yet unreliable speculation on their origins. It is nonetheless striking that the sources maintained a clear awareness of diversity in this area, which leads Bourdin (2012, 667-700) to describe the area as a "société multi-ethnique."

The Sidicini are the most straightforward. As Strabo points out, their name was preserved in the town Teanum Sidicinum, which is on the southern slopes of Mt. Roccamonfina. Coinage and inscriptions from the town are in Oscan. Strabo (5.3.9) calls the people Oscans, and “an ethnos of Campani that has disappeared.” Livy's detailed account of fourth century contests with the Sidicini has a counterpart in the Fasti Triumphales for 340/339: “[T.] Manlius L.f. A.n. Imperiosus Torquatus, consul \{III\}, over the Latins, Campanians, Sidicini and Aurunci, 15 k. Jun.” If we believe that the Fasti, at least for the later fourth century onwards, are reliable, this gives us a clear historical starting point.

The position with the Aurunci is much more complicated because there is a persistent identification of the Aurunci with the Ausones. Ausonia, however, was also used as a generalised term for an early Italic people. The developed mythography refers to a son of Odysseus called Auson, and Ausonia is used poetically to refer to all of Italy. (This is then mapped on to the archaeological phenomenon of "Ausonian culture” which was coined by Bernabò-Brea 1964-1965 to describe the Late Bronze Age culture of the Lipari islands and north-eastern Sicily, which is very similar to the Subappenine culture of the mainland). The connection of Auson with his son Liparos is recounted in Diodorus Siculus (5.7). The idea that the Ausonians spread from Campania all across Italy may also underlie Festus's abbreviated comment (16L) that Auson began in the area around Cales and Beneventum, and founded Suessa Aurunca. However, the tradition is extremely confused.

Hecataeus of Miletus, as mediated through Stephanus of Byzantium, is our first source for Ausonians in Campania; at BNJ 1 F61 he says that Nola was a city of the Ausones. This securely places early Greek knowledge of the Ausones in the right area, though Nola would not be considered part of Auruncan territory in historical times. Aristotle also puts the Ausonians on the west coast of Italy (Pol. 7.10. 1329b8-22), but it was not universal - when Pindar (F140 Maehler) refers to the Ausonian Sea it is in the context of Italian Locri. Lykophron is inconsistent, as is Apollonius of Rhodes, with locations wandering from the straits of Messina as far as Cerveteri. Pliny the Elder ( $\mathrm{NH} \mathrm{3.75,} 3.151$ and 14.69, and 3.95 citing Varro) has a more reduced notion of the Ausonian Sea, but a more expansive one at $\mathrm{NH} 3.56$.

By far the largest number of references to the Ausonians and Auruncans come from Silius Italicus, but his usage is poetical and imprecise. Virgil and Livy are more important for our purposes. Virgil perhaps more clearly than previous authors has a division between the Aurunci who were specifically located to the south of Latium, and the Ausonii who had a generalised role in the prehistory of Italy. The commentary tradition on Virgil represented in Servius reverts to a less nuanced version, 
summarised by the view that Ausones was simply the Greek name for Aurunci (Zannini 2012; see Pagliara 2008 and 2014b for more sophisticated readings).

It is only in Livy where we have a really clear and different view and that is because he is dealing with the historical period. Here the Aurunci are confined to the other side of Massico range, and concentrated around the Garigliano valley; the Ager Falernus is on the Campanian side of the mountain range; and the territory of the Sidicini extends inland from Roccafina towards Cales. Yet it is important to be clear that these boundaries were at no stage stable, and the description of Frederiksen $(1984,40)$ of a "shifting tessellation of administrative regions" nicely captures the situation.

Untangling this collection of sources into a single coherent historical thread is not possible; Pagliara has identified four different traditions, and there is an additional derivation of the Ausonians from a half-man half-horse figure called Mares, mentioned by Aelian (Var. Hist. 9.16; see Pagliara 2002, 2006, 2008 and the classic statements of Lepore 1989). It is clear that the majority Greek view was that there was an early Italic people of broad extent called the Ausoni, and that this is reflected in the way Latin writers use Ausonia, poetically, for all of Italy. There is a minority sceptical view that the Ausonians were none other than the Aurunci, who occupied no more than the coastal strip between the Volscians and Campanians (Dio Cassius F2.1 Boissevain, cited by the commentator Tzetzes). The more widely held view may have originated from the rhotacism that turned Aurunci into Ausoni, but there is little reason to believe that the Aurunci of the classical period, in northern Campania, were the wellspring of an Italic movement. How far, if at all, the Aurunci themselves exploited or promoted the story is not recoverable. Whilst it does seem clear that they did not see themselves as comparable to the Sidicini (and vice versa), the ethnographic tradition of a broad Ausonian culture arose elsewhere.

To understand more about these groups we have to turn to archaeology. However, it must be noted immediately that there is no clear list of which towns and settlements belonged to the Aurunci and Sidicini. Some may have been overtaken by the Volscians; di Fazio has suggested that a corrupt passage at Livy 8.22 may reveal that Fregellae, a long way up the Liris valley was once Sidicine territory (di Fazio 2014, 248), which would suggest both that Sidicine territory was much larger than we have tended to think, and that it was drastically reduced perhaps from the late sixth century on. With the cases of Teanum Sidicinum and Suessa Aurunca, we can clearly identify them from their names as key centres, but the latter is a Roman colony and the exact limits of the respective territories are never defined in antiquity, nor is the evidence sufficiently differentiated to permit us to distinguish on grounds of material culture alone (the allegedly national ceramic of the late orientalising period which Johannowsky very confusingly called bucchero rosso is instead a form of impasto with a red slip: Johannowsky 1983, 291-293; Chiesa 2011). It is also the case that there are a lot of gaps in our knowledge. Recent work around the two key sites in the Auruncan territory of Formiae and Fondi has begun to change 
this, but Pallottino's evocative description of this area as a zone of silence remains partially true (Pallottino 1984, 51).

\section{Prehistory}

The pace of discovery of prehistoric finds has picked up in recent years. The most extraordinary discovery was the footprints found in a pyroclastic flow off Roccamonfina dating to between 385,000-325,000 years ago, some of the earliest known human footprints. The tracks show bipedal hominids zig-zagging down the slope, sliding, and using their hands to steady their progress (Mietto, Avanzini and Rolandi 2003).

Some of the prehistoric evidence relates to coastal use, probably related to fishing. Caves near Gaeta in the Upper Palaeolithic show prolonged (October to May) human presence. Other traces of Palaeolithic to Neolithic activity have been found at various sites, with one of the most interesting being the cave at Rocca di San Sebastiani at Mondragone, where material has been found from 50,000 to 15,000 BC, including the possible interaction of Neanderthal culture and homo sapiens sapiens, traces of cave painting, evidence of hunting and gathering, including a quantity of horse bones and also cattle, goat, boar, wolf and vulture, and a child's milk tooth. At the large village of Arevito, also near Mondragone, around 3000 flint implements have been found. So we can see that the ecological possibilities of this area were substantial, and permitted a larger population than previously thought.

Around 3500 BC the development of more stable villages can be seen, for instance at Bagni Sulfurei. In the early Bronze Age, perhaps the most striking discovery has been the village at San Paolo Belsito (Nola), which was covered by the so-called Pomici di Avellino eruption of Vesuvius ca. 1750 BC. The inhabitants fled, leaving behind cooking utensils, drinking cups, hunting implements, a hat with wild boars' teeth as decoration, and a pot in the kiln about to be fired. A dog vainly took shelter inside one of the huts; its remarkably well preserved skeleton, one of the most complete for the period, shows an animal of about $42 \mathrm{~cm}$ to the shoulder and quite slender. (Traces of animals and humans fleeing this eruption have been found across the area, for instance at Afragola near Naples, in the mud of the river Clanis). The evidence for diet shows pig, sheep, and cow bones, pots of grain, and pregnant goats were being kept in an elevated pen.

As the Bronze Age draws on, and a drier climate makes the inland less marshy, and plough technology improves, we see the development of agriculture, and a move towards manufacture, evidenced by (for instance) a now largely lost bronze axe hoard from near Mondragone. There was a general shift towards more defensible sites. A site which well illustrates the late Bronze Age to early Iron Age transition is the romantically named "village of the cyclamens," on Monte Petrino on the slopes of Mondragone. A small number of huts have been found together with animal remains, including a tortoise, indications of weaving, local pottery manufacture, and 
a "Greek style" oinochoe and a leech style fibula and another a "foglia traforata," a type which we find in the lower Garigliano valley (Cifarelli 1996), and this reflects the potential connectedness of this area to the rest of central Italy. (For this period, see the collection of essays, Strategie di insediamento 2007).

The fact that we can find a good deal of occupation in the area is a better index of its fertility and agricultural and strategic potential, than of a deep-seated continuity of population. Rather, we should interpret the emergence of identities, expressed in ethnic terms, as historical phenomena, and dependent on the tensions and stresses produced by the increasingly dense and contested settlement. As we proceed into the archaic period, the connectedness we have just described begins to encourage the formation of distinct forms of self-expression.

\section{Archaic}

Notwithstanding important sites such as Monte Petrino, the Iron Age is currently rather poorly represented (Talamo 1987). Campanian cities such as Capua and Cumae develop strongly under the influence of Greek colonies, but the area to the north is much less clearly understood, and attested. Imports here are rare outside the coastal sites, and the cultural direction seems to be from and towards the Liris valley. This is in itself important. If one compares for instance the impact of Greek trade on coastal Etruria with inland Etruria, then we see clear evidence of acceleration of urbanization, production and acculturation. This is much harder to discern even in an area geographically closer to the Greek colonies and as we have seen, not lacking in agricultural potential.

This raises again the extremely difficult question of the ethnic identity of successful Campanian cities. If we consider Nola for instance, Hecataeus described it as Ausonian. Cesarano (2011) has explored the considerable evidence of Greek pottery in the Archaic period in the necropoleis of Nola, in the context of notions of cultural hybridity. However, this is a part of Campania which later on at any rate belonged to the Opici, not the Auruncans, and it is not even clear that it was part of the Sidicini; Cato the Elder thought it was Etruscan (Vell. 1.7.3), whilst Justin (20.1.13) preserves Pompeius Trogus' view that it was Greek, and yet the evidence for the Oscan language is clear. It may be that the definition of a group which would become the Auruncans, centred on the lower Garigliano river and the Monte Massico, and Sidicini, between Roccamonfina and Mons Tifata above Capua, was already under way by the seventh century, but it does not fully develop until a couple of centuries later.

A strong case for continuity and expansion may be made for Cales, which was probably part of the Sidicini. Burial evidence demonstrates that there were some wealthy individuals and more contact than we can trace in the lesser settlements. There is even the suggestion that the careful placing of the burials may have been part of the urban plan. Huts have been found from the seventh to sixth centuries, 
and in the sixth to fifth centuries a large tufa building was found on the site of a later cult of Mater Matuta, and architectural terracottas from elsewhere on the site show a developing urban culture. Contemporary burials include a very rich tomb from between 650 and $620 \mathrm{BC}$ with around a hundred objects in silver, bronze, iron, and various kinds of pottery. All are inhumations and clearly show the increasing influence of the Etruscans in the area, as well as connections to the Adriatic, especially through fibulae and amber is also present (Johannowsky 1983, 213-240; Gilotta and Passaro 2012).

For the other parts of the area, which would become the homeland of the Aurunci in the historical period, the eighth and seventh centuries are represented at the key sites of Monte Petrino, Suessa Aurunca and Alife in burial evidence and a votive deposit at Teanum. Survey work by Quilici and Quilici Gigli (2012) in the uplands of Monte Pianara and Monte Passignano above Fondi have begun to catalogue evidence of archaic fortified sites. Settlement across the whole region intensifies in the sixth century. Hints of conflicts with the Volscians to the north, for instance the capture of Tarracina (implied by its alternative name of Anxur; the fierceness of the struggle between Rome and the Volscians is suggested by Ennius and at Livy 4.59), mark out boundaries along the coast. To the south, Presenzano seems to have had strong Adriatic links and perhaps mediated them for the rest of the area. At the same time, pottery evidence, likely to be from a tomb near Teanum Sidicinum, suggests closer links with Etrusco-Latial pottery, and some Greek influence on decoration such as concentric rings, but there are also cups with an unusual high handle that seem to be influenced by Daunian shapes (Sirano 2008).

A critically important site is the shrine of Marica near the mouth of the Garigliano, not far from Minturnae (Mingazzini 1938; Ferrante, Lacam and Quadrino 2015, 107-118; Livi 2006). The first phase of the temple is dated to around $560 \mathrm{BC}$, and there is a restructuring around 500, and perhaps again after 400 . The reconstruction of the architectural form of the temple is unclear - it may have been peripteral, with a single central cella. Obvious parallels come to mind with other famous port sanctuaries like Pyrgi, but the extent of imported material at present seems less significant. The sanctuary has produced a much discussed Oscan inscription on an impasto bowl (actually two inscriptions on different parts of the bowl), which is translated in Imagines Italicae (1.359-61) as "Of Aufidius. Do not take me, I am with my three companions; at the (shrine) of the good gods."

Other sixth to fifth century sanctuaries are to be found near Teanum at Loreto and at Teanum itself (Fondo Ruozzo), the latter of which, dedicated to the goddess Popluna, has produced some spectacular terracotta figurines, including one of a female figure holding a piglet which may be the divinity herself (ca. $500 \mathrm{BC}$ ). The influence of Etrusco-Campanian terracotta is evident, and it has been suggested that the development of the sanctuary here reflects the emergence of a distinctive Sidicine culture (Sirano 2011a).

These sanctuaries offer a different way of understanding the region, which genuinely emphasises its distinctiveness. The sanctuary at Minturnae seems to have kept 
elements of its Archaic terracotta decoration into the Roman period, so that it accumulated visible layers of history, and was an amalgamation of different phases. A very large quantity of votive offerings show that the sanctuary remained popular, but as at Teanum, the locus of production seems to shift from a local to a more regional style. The highly distinctive large scale terracottas at Teanum, with unusual headdresses and with female figures with children on their shoulders (as distinct from the nursing mothers we see at Capua) all reflect a distinctive votive culture which is contemporary with the processes of individuation between the different groups in Campania. Cult and cultic practice here assists the development of identity (Livi 2006; Sirano 2015).

Samnite influence on southern Campania seems not to have affected the Monte Massico to the same extent as it did towns such as Pompeii and Capua, or the border areas of Alife and Presenzano (Rufrium), although the cult of Mefitis may be a Samnite import. Rather, the Aurunci and the Sidicini seem to have developed a sense of independence both from each other and from their neighbours, an independence which was not necessarily compromised by alliances. A model in which social networks expressed themselves - and were interpreted as - claims for ethnicity may provide a helpful model (see Blake 2014 for the Late Bronze Age). These emergent self-definitions met, and were perhaps caused by, the increasingly fraught external environment of the fourth century, when Campania became a place of intense contest (for what follows, see Pagliara 2014b; Sirano 2015).

\section{Roman conquest}

The Aurunci are first mentioned by Livy (2.16.8) in the context of an aggressive move against Cora and Suessa Pometia in the late sixth century. This move was more or less contemporary with the alleged first Roman colony at Segni. It is unclear what was the motivation for this intervention, though one might connect it with the Roman import of grain from Cumae, which is reported as early as 508 BC (Livy 2.9-14; Dion. Hal. Ant. Rom. 5.21-7, 32, 65). Livy must have found it mentioned in the Fasti Triumphales because he records a triumph at 2.17, but these early triumphs are not as certainly reliable as later ones. The tension returns in 495/494 BC when the Aurunci demanded the Romans withdrew from the area of the Volsci (Livy 2.26.4); one might wonder if the Aurunci were seeking to recover territory they had lost to the Voslci.

Ogilvie $(1965,276)$ was dismissive of this narrative, seeing the origin of the story in the similarity of Suessa Pometia and Suessa Aurunca. This may be too sceptical. The possibility of tension up and down the Liris valley is quite believable. We have seen that culturally the Aurunci of the Monte Massico area may have been connected through this routeway. As Campania started to move towards the rejection of its Etruscan population, perhaps the Aurunci looked to secure the vital riverway. We have mentioned the Volscian takeover of Tarracina, which led to its new name of 
Anxur. This must be connected with the broader challenges visible in Polybius' first treaty between Rome and Carthage (Polyb. 3.22), which demonstrates a Roman desire to control the coast some distance south. Formiae too may have spent some time under Volscian dominance, though this depends on the emendation of a highly fragmentary text of Festus (374L).

The same strategic concerns seem to underlie the next engagement in $345 \mathrm{BC}$. The Romans recovered the town of Satricum from the Volscians, and the following year were faced with an Auruncan raid. There is no need here to enter the debate over whether Satricum and Suessa Pometia were the same place (see for instance di Fazio 2014, 251); it is possible on either scenario to believe that the earlier engagement is a retrojection of the second, or that it reflects a genuine Auruncan concern. The consuls, Livy tells us, feared that this was part of a wider plot, but find that the Aurunci were just raiders. Then in 343 BC, the Samnites attacked the Sidicini, who had allied themselves with the Campanians, and Capua, which offered deditio or subordination to Rome, and the Romans were pulled into the First Samnite War (Livy 29.4-6)

The subsequent events are widely suspected to be inaccurately transmitted (see the commentary of Oakley 1997-2005 for a helpful guide). First, in 340 BC the Sidicini, having been rebuffed by the Romans, made an alliance against them with the Latins (Livy 8.2); Capua joined in, and the Romans confiscated territory. The Auruncans who had accepted Rome's victory were attacked by the Sidicini in 337, and before the Romans could react they were forced to abandon their city, and move to Suessa Aurunca, which they fortified (Livy 8.15.1-5). Then in 336, the Ausonians of Cales and the Sidicini joined forces against Rome, were defeated, retreated to Cales and were once more defeated. A garrison was put in place (Livy 8.16). In 314, in an atmosphere of tension and distrust, the Romans campaiged against the Ausonians. Aristocrats from the towns of Ausona, Minturnae and Vescia claimed their compatriots had been planning to support the Samnites after the Roman defeat at Lautulae. The Romans were assisted to enter the cities, and conducted an indiscriminate massacre. The Ausonian people, says Livy, was destroyed (9.15.9: deletaque Ausonum gens), and in the same year Capua was subjugated.

The Latin colony at Cales, founded in 335 BC, was a major move by Rome; with 2500 settlers, it was a substantial undertaking. Cales developed a highly distinctive pottery form which was made from the third into the second century. Formiae and Fundi received Roman citizenship without the vote in 334, allegedly as a reward, though shortly afterwards Fundi may have flirted with the rebellion at Privernum of Vitruvius Vaccus (Livy 8.19). The Auruncan territory was further organised into Roman space when Suessa Aurunca became a colony in 313, and Minturnae and Sinuessa in 295.

Teanum Sidicinum meanwhile flourishes from the fourth century onwards, and may in fact only attain urban form in this period, later than Cales. A famous pair of gold fibulae with stunning filigree and granulated decoration from the fourth century, now in Naples, attests to the wealth buried in the necropoleis. We have already 
mentioned the important votive deposits related to Teanum at Loreto and Fondo Ruozzo, which run from the sixth to the first century BC. Their distinctive figural votives and decoration have been examined by Sirano (2007), who emphasises the references to military activity. Several temple podia exist which were constructed between the fourth and third centuries. Geophysics undertaken by the British School at Rome shows a classic outline of an arx, with three gates, and then a lower city, encompassed by a polygonal masonry wall. The road structure divides the city into a rough grid, within which were built irregular insulae, and there is also evidence of the kind of innovative architecture of fora and porticoes, water management and shops, which we see elsewhere in central Italy (Sirano 2011b).

Teanum has produced a remarkable number of Oscan inscriptions, no fewer than thirty-five in Imagines Italicae. They range from a building dedications to dedications on pottery and an arula to Ceres and Pupluna. Around 300 BC, a potter called Plator comes to Teanum - his name is Messapian, he knew Greek and he specialised in his local black slip pottery with impressed decoration over-painted in white. He taught this technique to a workshop in Teanum belonging to the Berii, who, rather extraordinarily, annotated batches of pots as made at Teanum, implying perhaps that they had more than one workshop. Furthermore, we have intriguing evidence of a limestone slab, possibly an altar, from the third to second century, which has a magistracy tribuf plifriks, interpreted by some as a tribune of the plebs, and by Crawford as a calque on the aedile. It implies an interpenetration of concepts of magistracy, and also divisions in society between elite and non-elite which were being worked through in a constitutional manner (Imagines Italicae I.532-33).

In addition, we see coinage developing in both areas (Rutter 2001, 58-73). In Campania proper, sites such as Nola and Capua, under the influence perhaps of Naples, mint from the early fourth century. For our area the second quarter of the third century sees the development of coinage in a number of sites including Aesernia, Aquinum, Caiatia, Cales, Compulteria, Suessa Aurunca, Teanum Sidicinum, Telesia and Venafrum. There are strong parallels between the coin designs, both in silver and bronze, across the area, suggesting perhaps existing shared networks of exchange. The earliest are still in Oscan, and Hercules, Minerva, Apollo and Mercury are favoured deities.

What does seem clear is that the struggles with the Samnites and the Romans in the later fourth century, which forced decisions as to alliances and allegiances, ultimately also created an atmosphere in which social, economic and cultural development could accelerate (Sirano 2015). Most sites develop polygonal masonry walls, and some at least predate the Roman conquest. Since Teanum Sidicinum at any rate does not seem to have become a colony until the time of Augustus, we have to develop a more nuanced model of what drove this rather than simply reverting colonization as an explanation.

We still need to understand better the relationship between Teanum and its territory, but it already offers a case study in regional diversity. Many of the major sites nearby face inland - Capua, Cubulteria, Saticula, Allifae, Rufrium, Venafrum and Ca- 
sinum are all border sites. Interesting lesser sites like Trebula Ballensis (Caiazza and Pagano 2012), with finds from the Bronze Age to the late imperial period, monumental walls and a fourth century heroon built up against them, or Mignano Montelungo, with occupation from the fourth century $\mathrm{BC}$ to the sixth century $\mathrm{AD}$, show an extraordinary network of highly successful and resistant settlements (de Caro and Miele 2001). This is the vibrant world which entered the Roman orbit.

\section{Romanization}

It is notable that the earliest Roman settlements were fora, not colonies, and that the urban pattern of Rome was not the basis of their first organization. This is in the area which the Romans called the Ager Falernus, on the southern slopes of M. Massico, where the two settlements of Forum Claudii and Forum Popilii may represent the earliest mechanism for organising the area. The Ager Falernus was land taken from Capua in 340 BC; it was highly fertile and would become the source of some of Italy's most sought-after wine (Arthur 1982, 1991; Purcell 1985; Guadagno 1987). Centuriation is also found here, as across the whole area, and its careful study offers many possibilities for an enhanced understanding of the area (Chouquer, Clavel-Lévêque and Favory 1987).

It was during the Second Samnite War that Rome moved to establish clear control of the Auruncan territory, and to a degree the coast, through its colonies. The two most immediate consequences of the Roman control of this area have been thought to be improved drainage and centuriation. Whether the drainage is older is not clear. In other parts of central Italy, cunicoli are dated to the sixth century, but it has been suggested that the drainage around Cales for instance is driven by the Roman presence (Ødegard 1997; cf. Sevink 1985).

In addition, the Romans built roads through the area, the Via Appia first and foremost, and the Via Latina, but overall a rich network of connections supported the development of markets and minor centres, amongst which may have been two pagi attested only epigraphically, the Pagus Vescinus and the Pagus Sarclanus, the latter of which might have a pre-Roman name (Pellegrino 1978). These may have been established on the basis of existing centres, though other interpretations would view them as Roman creations. Clearly this vexed question bears directly on the nature of Auruncan settlement prior to the Romans, but further evidence is required.

The strong road network paradoxically made it easier for Hannibal to penetrate the area in $211 \mathrm{BC}$ in his march from Capua to Rome. Interestingly there is no suggestion that he was aided by either the Sidicini or the Aurunci - Livy (26.9.1) says that Hannibal laid waste to the area and Silius Italicus (5.551 ff.) hints that the Sidicini remained loyal. Cales was one of the twelve colonies who refused to support Rome, however, and needed to be reinforced. Cult sites, such as the one at Panetelle where some very scarce early material gives way to a second century temple, and that of Marica, already mentioned, continued through to the end of the first century, 
and it may be that they continued to serve a still rural population until the Social War.

The second century does seem on the whole to be a period of reorganization and growth. The improvement of the soil and its fertility seems to have laid the basis for an increasing concentration of land ownership - there is an impressive growth in villas across the area, not least in the attractive coastal areas. Arthur (1991) counted fourteen villas before the Second Punic War and over a hundred in the second and first centuries around M. Massico; much of this was being driven by the trade in wine, as attested by signs of presses and amphora manufacture. Municipal life in the towns and colonies develops with reorganised town plans, and the usual emergence of civic space, fora and public buildings. At some stage, Fundi and Formiae received citizenship and demonstrate both in their urban structure and territory rapid growth and increase in wealth (di Fazio 2006, 65-92; Mesolella 2012, 225-283). Impressive theatres and amphitheatres were built in the late Republic and early empire. Small road stations and the fora continue to provide a web of connection and communications across the area, and the Via Domitiana ran alongside the coast from Sinuessa to Naples to join up the Italian port network including Puteoli. Wine and amphora production seem to function strongly into the second century AD, and Minturnae and Suessa Aurunca continue to operate as significant ports. However, there does seem to be a decline in the third century, as economic conditions worsened.

Suessa Aurunca is now largely built over, though its theatre and part of its walls have been uncovered. A cryptoporticus may relate to the theatre, which was adorned with statues of the imperial family. Further buildings related to bath buildings or nymphaea have left traces and there was also an amphitheatre, and at least one aqueduct. Suessa received particular benefactions from Hadrian's grand-niece Matidia, including a library (Cascella and Ruggi d'Aragona 2012).

Minturnae, just upriver from the shrine of Marica, shows evidence of its forum, defences, and a complex of two temple, tabernae and a theatre. The port is not wellknown, but was substantial and epigraphy reveals evidence of shipbuilding, carpentry, and salt-pans. Cato the Elder (Agr. 135.1) in the second century recommended Minturnae as a centre for iron-working, which shows one way in which Minturnae operated within trading networks, since it had no mineral resources of its own, but perhaps drew from resources further up the Garigliano-Liri, for instance Monto della Meta. A set of bath buildings attached to a spring at Aquae Vescinae, and a very large villa at Scauri by the coast might have belonged to M. Aemilius Scaurus (cos. 115 BC) (Bellini and von Hesberg 2015; Ferrante, Lacam and Quadrino 2015, 87-130; Mesolella 2012, 109-224).

Sinuessa was the object of substantial private largesse - Vespasian supported it, Vitellius robbed it and one L. Papius Pollio commemorated his father's death with gladiatorial games and a feast (CIL I ${ }^{2}$ 1578). The foundations of the large amphitheatre have been half uncovered. Various nearby local settlements have been uncovered, including an important bath complex at Thermae Sinuessanae, which was widely famed (Crimaco and Gasperetti 1983). 
Teanum Sidicinum became a colony under Augustus, and continued to thrive. A major temple-theatre complex was constructed in the later second century BC and rebuilt under Augustus, and extended under Septimius Severus. An amphitheatre and bath complex complete the standard urban set-up, and Teanum continued in prosperity into the fourth century AD (Sirano 2011b). Cales (mod. Calvi Risorta), with its well-preserved remains of walls, amphitheatre, theatre and baths, has a similar history of urban development and persistence. The two towns are linked by a famous story, told by the radical tribune C. Gracchus (Gell. NA 10.3), of a magistrate at Teanum Sidicinum who was flogged for not emptying a bath building in time for a visiting Roman magistrate's wife to use it; news rapidly reached Cales which banned everyone from the baths if a magistrate was present. Gracchus uses this as an indication of the high-handedness of Roman magistrates, but co-existence between Roman and local elites may have been more usual.

Epigraphy and the literary sources have revealed the names of some benefactors and landowners across this area; they included Cicero and various of his friends, Pompey the Great, and the Papii, originally from Samnium, who seem to have been major owners. Marius fled across the territory of Minturnae to escape from Sulla, and the heavy presence of supporters of Sulla, and indeed his son, in the area may show that Sulla confiscated territory there. Major assignations of veterans in the first century AD may have disrupted some of these patterns, and at least some of these estates then came into imperial ownership. Local magistracies are well-attested in epigraphy and some individuals make their way to high office. One example is C. Fulvius Plautianus, prefect of the praetorian guard under Septimius Severus, whose name was inscribed on a monument in the restored theatre at Teanum Sidicinum, which then suffered damnatio memoriae, eventually ending up reworked as part of the decoration (Sirano 2011b, 119).

By the late empire, Campania was characterised by high taxation and low population. The Aurunci and Sidicini as ethnic groups were now merely antiquarian memories. The Lombard invasions damaged the interrelationships on which the success of the earlier period had been based, and all the major centres appear weakened or abandoned by the sixth or seventh centuries. Sources refer to marshy conditions, suggesting the abandonment of drainage activity, and it was several centuries before the area would recover (Vitolo 2005).

\section{Bibliography}

Arthur, P. "Roman amphorae and the Ager Falernus under the Empire." Papers of the British School at Rome 50 (1982): 22-33.

Arthur, P. Romans in Northern Campania: settlement and land-use around the Massico and the Garigliano Basin. London: British School at Rome, 1991.

Bellini, G. R. E. and H. von Hesberg. Minturnae: nuovi contributi alla conoscenza della Forma Urbis: Giornata di studio sui lavori a Minturnae, in collaborazione con la Seconda Università degli studi di Napoli, Facoltà di Lettere e Filosofia, Roma, 29 settembre 2011. Roma: Quasar, 2015. 
Blake, E. Social Networks and Bronze Age Identity in Regional Italy. Cambridge: Cambridge U. P. 2014.

Bourdin, S. Les peuples de l'Italie préromaine: identités, territoires et relations inter-ethniques en Italie centrale et septentrionale (VIII $-I^{\text {er }}$ s.av. J.-C.). Bibliothèque des écoles françaises d'Athènes et de Rome 350. Rome: Écoles françaises de Rome, 2012.

Brea, L. B. "Leggenda e archeologia nella protostoria siciliana." In Kokalos, 10-11. Atti del I congresso internazionale di studi sulla Sicilia antica, 1-34, 1964-1965.

Caiazza, D. and M. Pagano. "Trebula Baliniensis la Pompei dell'insediamento megalitico." In Quarto seminario internazionale di studi sulle mura poligonali, Palazzo Corti Gentili, 7-10 ottobre 2009, edited by L. Attenni and D. Baldassare, 55-64. Roma: Arachne, 2012.

Cascella, S. and M. G. Ruggi D’Aragona. Memorie suessane di Matidia: Suessa: città e territorio dagli Aurunci all'età romana. Oxford: Archaeopress, 2012.

Ceserano, M. "Nola polis degli Ausoni nella Periegesi di Ecateo alla luce dell documentazione dalle necropoli." Incidenza dell'Antico 9 (2011): 143-168.

Chiesa, F. "Contatti di culture nel quadro archeologico di Cales." ACME. Annali della Facoltà di Lettere e Filosofia dell'Università degli Studi di Milan 64.2 (2011): 65-87.

Chouquer, G., M. Clavel-Lévêque and F. Favory. Structures agraires en Italie centro-méridionale: cadastres et paysages ruraux. Rome: Ecole française de Rome, 1987.

Cifarelli, F. "Sulle fibule in bronzo del tipo a Foglia Traforata: cronologia e diffusione." SE 62 (1996 [1998]): 3-26.

Crimaco, L. and G. Gasperetti. Prospettive di memoria: Testimonianze archeologiche dalla città e dal territorio di Sinuessa. Napoli: Ministero per i Beni Culturali e Ambientali, Soprintendenza Archeologica per le province di Napoli e Caserta, 1993.

De Caro, S. and F. Miele. "L'occupazione romana della Campania settentrionale nella dinamica insediativa di lungo periodo." In Modalità insediative e strutture agrarie nell'Italia meridionale in età romana, edited by E. Lo Cascio and A. Storchi Marino, 501-581. Bari: Edipuglia, 2001.

Di Fazio, M. Fondi ed il suo territorio in età romana: profilo di storia economica e sociale. Oxford: Archaeopress, 2006.

Di Fazio, M. "I Volsci: prospettiva storica." In Tra archeologia e storia: dialoghi sulle popolazioni dell'Italia preromana. Vandoeuvres/Ginevra, Fondation Hardt 2013, edited by M. Aberson, M. C. Biella, M. Di Fazio and M. Wullschleger, 245-257. Frankfurt a.M.: Peter Lang, 2014.

Ferrante, C., J-C. Lacam and D. Quadrino. Regio I, Fondi, Formia, Minturno, Ponza. Fana, templa, delubra. Corpus dei luoghi di culto dell'Italia antica (FTD) 4. Roma: Quasar, 2015.

Frederiksen, M. Campania. London: British School at Rome, 1984.

Gilotta, F. and C. Passaro. La necropoli del Migliaro a Cales: materiali di età arcaica. Roma: Istituto Nazionale di Studi Etruschi ed Italici Monumenti Etruschi, 2012.

Guadagno, G. Storia, economia ed architettura nell'Ager Falernus: atti delle Giornate di Studio, febbraio - marzo 1986. Minturno: Archeoclub d'Italia, Sede di Falciano del Massico, 1987.

Imagines Italicae $=$ Crawford, M. H. Imagines Italicae: a corpus of Italic inscriptions (3 vols.). Bulletin of the Institute of Classical Studies supplement 110. London: Institute of Classical Studies University of London, 2011.

Johannowsky, W. Materiali di età arcaica dalla Campania. Monumenti antichi della Magna Grecia 4. Napoli: G. Macchiaroli, 1983.

Lepore, E. Origini e strutture della Campania antica: saggi di storia etno-sociale. Bologna: Il Mulino, 1989.

Livi, V. "Religious locales in the territory of Minturnae: aspects of Romanization." In Religion in Republican Italy. Yale Classical Studies 33, edited by C. E. Schulz and P. B. Harvey, 90-116. Cambridge: Cambridge U. P., 2006. 
Mesolella, G. La decorazione architettonica di Minturnae, Formiae, Tarracina: l'età Augustea e Giulio-Claudia. Roma: "Erma” di Bretschneider, 2012.

Mietto, P., M. Avanzini and G. Rolandi. "Palaeontology: human footprints in Pleistocene volcanic ash.” Nature 422 (2003): 133-133.

Mingazzini, P. Il Santuario della Dea Marica alle foci del Gargliano. MAL 37. Milano: Hoepli, 1938.

Oakley, S. P. A Commentary on Livy Books VI-X. Oxford: Oxford U. P., 1997-2005.

Ødegard, K. "Drainage and colonization: the case of Cales." ATTA 2 (1997): 213-224.

Ogilvie, R. M. A Commentary on Livy I-V. Oxford: Oxford U. P., 1965.

Pagliara, A. "Silloge delle testimonianze letterrie greche e latine sugli Ausoni e gli Aurunci." In In Memoria di Luigi Bernabo Brea, edited by M. B. B. M. Cavalier, 193-246. Palermo: Sicilia. Assessorato dei beni culturali e ambientali e della pubblica istruzione, 2002.

Pagliara, A. "Gli Aurunci in Livio." Oebalus 1 (2006): 11-19.

Pagliara, A. "L'immagine degli Ausoni-Aurunci nella letteratura classica." In Dalle sorgenti alla foce: il bacino del Liri-Garigliano nell'antichità: culture, contatti, scambi: atti del convegno, Frosinone-Formia, 10-12 novembre 2005, edited by C. Corsi and E. Polito, 3-13. Roma: Quasar, 2008.

Pagliara, A. "I Campani: prospettiva storica." In Tra archeologia e storia: dialoghi sulle popolazioni dell'Italia preromana. Vandoeuvres/Ginevra. Fondation Hardt 2013, edited by M. Aberson, M. C. Biella, M. Di Fazio and M. Wullschleger, 281-297. Frankfurt a.M.: Peter Lang, $2014 a$.

Pagliara, A. “Qui primi coluisse Italiam dicuntur (Gell. 1, 10, 1).” MEFRA 126 (2014b): URL: http:// mefra.revues.org/2342.

Pallottino, M. A History of Earliest Italy. London: Routledge, 1984.

Pellegrino, A. "Iscrizione da Mondragone." Sesta Miscellanea Greca e Romana (1978): 383-394.

Purcell, N. "Wine and wealth in ancient Italy." Journal of Roman Studies 75 (1985): 1-19.

Quilici, L. and S. Quiligi Gigli "Organizzazione del territorio a Fondi, tra bonifiche e romanizzazione." ATTA 22 (2012): 155-310.

Rutter, N. K. Historia Numorum Italy. London: British Museum, 2001.

Sevink, J. "Physiographic soil surveys and archaeology." In Papers in Italian archaeology IV: the Cambridge Conference, edited by C. Malone, 41-52. London: British Archaeological Reports, 1985.

Sirano, F. "La cultura figurativa sidicina nel quadro della Campania settentrionale di età arcaica." ConvStEtr 26 (2011a).

Sirano, F., editor. Il teatro di Teanum Sidicinum: dall'antichità alla Madonna delle Grotte. Villa d'Agri (PZ): Lavieri, 2011b.

Sirano, F. (2015). "La romanizzazione dei luoghi di culto della Campania settentrionale. Proposte di lettura del dato archeologico tra ager Falernus, area aurunca e sidicina." In The Impact of Rome on Cult Places and Religious Practices in Ancient Italy. BICS Supplement 132, edited by T. D. Stek and G.-J. Burgers, 199-238. London: BICS, 2015.

Strategie di insediamento $=$ Atti della XL riunione scientifica strategie di insediamento fra Lazio $e$ campania in età preistorica e protostorica: Roma, Napoli, Pompei, 30 novembre - 3 dicembre 2005: dedicati ad Amilcare Bietti. Roma: Istituto Italiano di preistoria e protostoria Riunione scientifica, 2007.

Talamo, P. L'area aurunca nel quadro dell'Italia centromeridionale: testimonianze archeologiche di età arcaica. Oxford: B.A.R., 1987.

Vitolo, G. Le città campane fra tarda antichità e alto Medioevo. Salerno: Laveglia, 2005.

Zannini, U., editor. Isti (Aurunci) graece Ausones nominantur. Sessa Aurunca - 10 maggio 2009. Marina di Minturno: Caramanica Editore, 2012. 